\title{
Humanizing the Classroom: Praxis of Full Day School System in Indonesia
}

\author{
Suyatno $^{1} \&$ Wantini $^{2}$ \\ ${ }^{1}$ Department of Educational Management, Ahmad Dahlan University, Yogyakarta, Indonesia \\ ${ }^{2}$ Department of Islamic Education, Ahmad Dahlan University, Yogyakarta, Indonesia \\ Correspondence: Suyatno, Department of Educational Management, Ahmad Dahlan University Jalan Kapas \\ Nomer 9 Semaki, Yogyakarta, Indonesia. E-mail: suyatno@pgsd.uad.ac.id
}

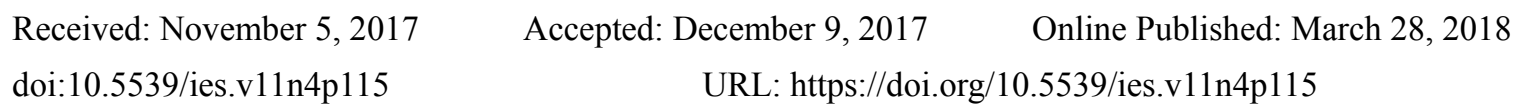

\begin{abstract}
The full day school program is a new model in the education management system in Indonesia. This phenomenon is interesting because there is a paradox in it. Education in Indonesia is often criticized for the learning which is too heavy, but the full day school program gets a positive response from the community although it has longer school hours. This research aims to answer the questions; 1) How is a full day school praxis program in Indonesia? Second, how is the implementation of humanizing the classroom learning program in schools that implement the full day school program? This research is a qualitative research with locus at Islam Terpadu Salsabila Elementary School (SDIT Salsabila), Yogyakarta. Research subject is determined by purposive sampling. Method of data collections are: 1) participant observation, 2) in-depth interview, 3) questionnaire, and 4) document analysis. Data analysis technique is inductive-qualitative. The results are; First, the full day school program in Indonesia is growing as a result of the increasing number of busy working parents. They do not have the opportunity to accompany their children at home because they are busy working from morning to evening. The full day school program is an educative solution for them. Secondly, humanizing the classroom is implemented through students' active involvement in the classroom and the learning process is democratic and fun. This approach is a solution so that students do not feel boredom in learning although they spent their time throughout the day at school.
\end{abstract}

Keywords: humanizing, students as learning subject, full day school

\section{Introduction}

In the past two decades, educational institutions in Indonesia have experienced shift in its management system. This is marked by the spring of schools that apply the system of full day school, the school that implements a full day of learning, between the hours of $7 \mathrm{am}$ to $4 \mathrm{pm}$. This is a new phenomenon because in the previous decade, mostly the school learning hours implemented a half day system, from 7 am to $1 \mathrm{pm}$.

Awareness about the importance of education is the main reason, in addition to other technical factors such as wanting to entrust their children because parents are busy working until the evening so that children do not spend their time to watch television and neglect learning. In fact, as the development of information and technology, children often spend their time in front of the gadget. Most parents who send their children to school with a full day school system is because they feel less able to provide good mentoring when their children are at home. Elicker \& Mathur (1997) described three factors that led to the growing of schools with full day system; First, many parents are busy working outside the house so they leave their children at schools with a full day system. Second, teachers in schools face difficulties in meeting the demands of the curriculum when the learning schedule is only half day. Third, the curriculum demands that fit the current development era takes longer time in integrating student-centered learning models and experiential learning.

The full day school program is not only developing in Indonesia. The full day school has long been applied in several countries, such as Singapore, South Korea, China, Japan, United Kingdom, USA, Taiwan, Spain, Denmark and Germany. The Harvard Family Research Project published research result in 2003 which stated that a full day school program can improve the children's social and personality development, in addition to academic achievement. Gottfredson et al. (2004), who conducted research on students in Maryland in 1999-2000 revealed that the participation of students in schools with a full day school system can reduce behaviour problem, especially 
in secondary education students. There are two notes in the results of Gottfredson's research, as quoted in Winurini (2016). First, the decline in behaviour problem is not gained by narrowing the blank space for adult supervision or by increasing student involvement in constructive activities. Second, the activity that most contribute to the decline in behaviour problem is social competence development activities and personality. The opposite research results are explained by Burdumy, Dynarski, and Deke (2006). Through the result of the research released in 2006, they stated that the full day school program can increase the negative behaviour of male students in primary education and students who previously did have disciplinary problems. Vandell and Shumow as quoted from Winurini (2016) revealed that the utilization of full day school depends on the children's opportunity to make decisions and positive climate created in schools that relate to the ratio of learners with the children and the qualifications of those learners. Holm (2014) stated that the full day school system is found many in Denmark especially in cities with areas of high concentration of ethnic minority students.

Heagle, Timmons, Hargreaves, and Pelletier (2017) mentioned that there is no significant difference in academic ability of children who go to half-day school and full day school, but the results of his research indicate the importance of learning while playing, both in half-day and full day school programs. Basketta, Bryanta, Whitea, and Rhoads (2005) mentioned that children who attend full-day school program have improved better than children who attend school with half-day program. In addition, parents also show high levels of satisfaction with full-day school programs.

There are reasons that need to be studied from the implementation of full day school program in Indonesia. This is because all this time many criticism towards the implementation of education in Indonesia which is considered too burdensome for students. Students are burdened because the curriculum contains too many subjects. Coupled with a full day school system, of course the student's burden will be more and more, because students have to spend their time from morning until evening at school.

However, the wider community tends to respond positively to the existence of full day school. They do not worry that their children feel burdened by the system. This is because despite a full day of study, they still get enough hours to play. In fact, the learning motto is learning while playing. Learning is created in a fun situation so students do not feel overwhelmed. They practice, by borrowing the term of John P. Milner, humanizing the classroom, the learning process that humanizes the class (read: children who are studying in class). Students are treated according to their own talents and uniqueness. The core of learning is to raise self-awareness or consciousness as the base of creative intelligence.

With fun learning, students feel comfortable in school and this comfortable feeling can improve learning outcomes. Therefore, researchers are interested to examine more in depth about the learning implementation that uses the principle of humanizing the classroom in schools with a full day school system. Based on the background of the above problems, there are two problems formulation in this research: first, how is the praxis of full day school system in Indonesia? Second, how is the implementation of humanizing the classroom learning in school that implements full day school system?

\section{Method}

This research is a qualitative phenomenological research by taking locus at SDIT Salsabila Yogyakarta. The determination of sampling in phenomenological research involves identifying and determining the location of the participants who have been or are experiencing the event being studied (Miles \& Huberman, 1994; Patton, 2002; Rudestam \& Newton, 2001). The subject of the research is done by purposive sampling method, which is sampling process based on the purpose of data collection (Johnson \& Cristensen, 2008; Miles \& Huberman, 1994). All selected informants have the potential to contribute to the collecting of necessary data to answer the research problems (Cohen et al., 2000; Johnson \& Cristensen, 2000). Research subjects consist of principal, teachers, students, and parents of students. Data collection methods are; 1) observation, 2) interview, 3) questionnaire, and 4) document analysis. Data analysis technique is inductive-qualitative which includes data reduction, data display and conclusion (Miles \& Huberman, 1994).

\section{Literature Review}

Humanizing the classroom is a combination of the word "humanizing" and "the classroom". Thus, literally, humanizing the classroom can be interpreted to humanize the classroom. However, in more broad terms humanizing the classroom means teachers should provide treatment to students in accordance with the talent and uniqueness of each student. The concept of humanizing the classroom is the implementation of humanist education theory in learning.

Reardon (2001) revealed that the core of humanizing the classroom is to implement student-centered learning. 
Students are treated as whole human beings who act as subject of learning, not object of learning (Reardon, 2001). This opinion is reinforced by Nwafor and Nwogu (2014) who stated that humanizing the classroom is the process of humanizing students as human beings who have cognitive, affective and psychomotor aspects.

Nwafor (2014) revealed that the basic elements of humanizing the classroom are teachers and students as learners. No matter how good the school building, curriculum, and school infrastructure, it will not mean much if not given the human touch by educated and dedicated teachers, and students with high passion and curiosity. It is also similar with Bhatia (2000). Bhatia (2000) revealed that in the process of humanizing the classroom, teachers have an important role. Teachers play an important role in humanizing the classroom and even outside the school environment. Teachers are an important factor in the educational process. Moreover, good teachers give their students opportunities to think while learning is taking place (Okorie, 1986; Onoguere, 2000).

Nwafor (2014) added that humanization in the context of the class means the process of giving their attributes and values such as honor, respect, love, dignity, friendship, social status, age, and education level to others. This approach is based on the theory of humanism, which is a belief system related to human needs, and the restoration of human values that can be universally accepted. Nwafor (2014) also stated that in recognition of this, existentialists argue that teachers should pay attention to the unique personalities of each student, and they should seek to relate to the students with the term "I-you" rather than the relation of "I-it"

Almost in accordance with previous opinions, Kuntoro (2008) mentioned that humanist education is adopted from two schools of education namely the flow of progressivism and existentialism. Principles of humanist education derived from progressivism namely; children-centered education, non-authoritarian teacher roles, focuses on student engagement and activities, and democratic and cooperative education aspects. Therefore, Kuntoro (2008) also mentioned that educators in the learning principle of humanizing the classroom, has the following educational paradigm:

a) Educational objectives and processes are children's initiative. Therefore, the curriculum and educational objectives must be in accordance with the needs and interests of children.

b) The student is an active subject, not a passive object. Children will enthusiastically learn if they are given the opportunity to learn according to their talents and interests, not because of coercion from the teacher.

c) Teachers as facilitators are assigned to advise, guide, and study partners, not class rulers.

d) School is a society miniature. Therefore, education activities are not limited to activities in the classroom, but the activity of education can provide benefits to the community.

e) Learning activities to be more focus on problem solving, not just transfer of knowledge from teacher to students.

f) School climate must ensure a democratic and cooperative atmosphere.

In addition to adopting the flow of progressivism, humanist education also adopts the idea of existentialism flow, namely the appreciation of the student as a unique person. Each student is considered to have different talents and interests. Therefore, they are also given different treatment. The teacher in humanizing the classroom should give freedom in the individual to choose what is right for him or herself so that each individual builds him/herelf to become what he/she wants (Kuntoro, 2008).

Mulkan (2001) stated that humanizing the classroom is one form of learning model which is based on the value of humanity. The value of humanity serve as the basis for a better learning. Still according to Mulkan, humanizing the classroom has three main focuses or goals. The focuses of this learning model are: first, aware that him/herself as a process of growth that is and will constantly changing, second, looking for concepts and self-identity, and last, combine the consciousness of heart and mind. Titus et al. (1979) stated that the concept of humanization seems to be in tandem with the existentialist philosophy, the fundamental drive or urge is to exist and to be recognized as an individual.

\section{Results}

The discussion in this section is divided into two important points about full day school praxis in Indonesia and the implementation of humanizing the classroom in SDIT Salsabila Yogyakarta.

\subsection{Praxis of Full Day School System in Indonesia}

Praxis of fullday school system in Indonesia has been running since two decades ago. This can be proved by the growth and development of Islam Terpadu (Islamic Integrated) schools in Indonesia, especially in big cities, which almost all Islam Terpadu Schools implement a full day school system. This model is then imitated by other 
schools, especially Islamic schools, both Muhammadiyah schools and Ma'arif schools. Many factors affect the development of schools that implement the system full day school.

There is a real consideration of most parents who choose schools with a full day system. Dina (2011) explained that schools with full day system are increasingly in demand by the community because of the longer study time in school. Arsyadana (2010) stated that schools with full day system emerging because of some points. First is less good environment of society. Second is the lack of parents to accompany their children due to job demands, social, or anything which keep parents busy. Third is the children's tendency at home who just playing and lazy to learn.

Andikurrahman (2012) explained that full day school system can have the following impacts; lack of social interaction in learners, lack of confidence in learners, and low social sensitivity in learners. For teachers, the full day school program makes their tasks harder. The full day school system is reeged unity between the various components of the school and especially the guardian/parents of the pupil as the controller and creator of home study atmosphere (Wahidun, 2008).

Research on full-day school programs has been widely conducted (Puleo, 1987). Some research results revealed the full-day school impact on students' development, all in academic, social, and emotional development. Cannon, Jacknowitz, and Painter (2006) explained that schools implementing full-day program in order to improve students' achievement. The full-day school program aims to improve academic, socio-emotional, and cognitive (Kauerz, 2005). This is consistent with research findings which showed that students' achievement is cumulative, and quality education will lead to children's success in the future (Pianta, Cox, \& Snow, 2007). Other findings revealed that students who attend schools that apply full-day system are better prepared both academically and socially as they enter the next level of education compared to students from half-day school system (Cooper, Allen, Patall, \& Dent, 2010; Ray \& Smith, 2010). The results of Clark and Kirk's (2000) research concluded that full day school program can improve academic achievement, socialization and behavioural control, as well as parents and teachers attitudes. The researches of Fusaro and Royce (1995) and Gullo (2000) found that children in schools with full-day system have more academic readiness than children in schools with half-day system. In contrast to general researches, Sergesgetter and Gilman (1988) found that there are no significant differences between children who studying in full-day school and half-day school.

The results of the above researches, although there is no uniformity of findings, generally indicate that the application of full-day school system has many positive impacts for students, all on the aspect of academic, social, emotional development, students' readiness in the next level of education, even parents' satisfaction to the achievement of their children's learning.

These findings are reference for education practitioners in Indonesia to develop a school that uses a full-day school system. Through interview, a teacher explained that:

The full-day school program is developed because it matches the interests and expectations of the community. In addition to the busyness factor, the full-day program also proved to be very beneficial for the children's own development. With longer learning hours, school is more able to develop programs which exist in school, both in the nature of academic and character development (Interview with teacher of SDIT salsabila).

In addition, the increasing interest of the community towards full-day school program became the main reason to get students as much as possible. Many parents send their children to SDIT Salsabila because the school implements full-day school program. Through interview, parent stated that:

I send my child to SDIT Salsabila because its full-day, where we are busy working, then we need to choose an institution we can trust to take care of the children. To take care means keep cultivating goodness during our work (Interview with B, Parent of 5th Grade Student of SDIT Salsabila).

The same thing was revealed by K, parent of $1^{\text {st }}$ grade student of SDIT Salsabila Yogyakarta:

I send my child to SDIT Salsabila, first because of its full-day. I work every day from morning to evening, have duties in some hospitals, and also open practice, while my husband is an entrepreneur, has been very busy with our respective works, so the child needs to be taken care by people that we trust capable, and the religious can also develop well, eventually fall of choice on SDIT Salsabila (Interview with K, 1st grade student of SDIT Salsabila).

The full-day school system provides longer academic time than any general education program. A long academic time is required in order to train children's social skills. The full-day program in SDIT Salsabila, the school time is $7 \mathrm{am}-3 \mathrm{pm}$ for low grade which are $1^{\text {st }}-3^{\text {rd }}$ grade, while for upper grade, which are $4^{\text {th }}-6^{\text {th }}$ grade, the school time is $7 \mathrm{am}-4 \mathrm{pm}$ (Documentation of SDIT Salsabila Activity Schedule). 
The full day school system is beneficial for the urban middle class and busy working parents. By sending their children to school with a full day school system, they do not need much money to care for their children. In fact, they do not have to worry about the activities their children are doing after school because the children are full-day at school until the evening when the parents are home from work. This is considered an alternative solution when parents are overwhelmed with concerns about moral damage among young people whether caused by illegal drugs, promiscuity, and other types of juvenile delinquency. They only need to pay a little extra money for extra-curricular activities which on average is no more than 600,000 rupiah each month. This amount is a little more expensive compared to other schools as a consequence of the full day shool system (Hasan, 2011).

As a consequence of the full day school program, schools need additional facilities including have to provide lunch and monitoring the children for a full day. Most of the upper middle class, especially for civil servants parents, they prefer to send their children to school with a full day school system. This is also in accordance with working hours in Indonesia (from $7 \mathrm{am}$ to $1: 30 \mathrm{pm}$ for six working days and $8 \mathrm{am}$ to $4 \mathrm{pm}$ for five working days) leaving parents with no time to take care of their children. Therefore, the full day school system is considered a practical solution for them.

Because it is considered as an alternative, parents are willing to pay higher education fees compared to schools in general. The entrance fee at SDIT Salsabila ranges from Rp. 2,000,000-Rp. 3,000,000 and monthly education donation Rp. 350,000 to Rp. 400,000 per month (Interview with Z, Teacher of SDIT Salsabila). The tuition is quite high compared with the tuition be paid by parents if the children to enter Public Elementary School or Madrasah Ibtidaiyah (equivalent to elementary school, which management is carried out by the Ministry of Religious Affairs). Even, both types of educational institutions are free of charge as the program from the government.

The latest development, the 8 hour day school program (although not formally called the full day school program) has been adopted by the government, in this case the Ministry of Education and Culture implement this program nationally, albeit alternatively. Full day school is considered fit to strengthen character education program, the branding of the current government education. This policy was originally stipulated in Regulation of the Minister of Education and Culture No. 23 of 2017. Many responses of pros and contras toward the policy, and ultimately this policy is revised by Presidential Regulation number 87 of 2017. The Presidential Regulation is a substitute of the Regulation of the Minister of Education and Culture No. 23 of 2017.

\subsection{Implementation of Humanizing the Classroom in School}

SDIT Salsabila is one of the schools that implement full day school system in Yogyakarta. SDIT Salsabila has a vision of the realization of Qurani golden generation Indonesia 2045 that are capable, intellectual, and noble. This vision is prepared by the foundation managers together with stakeholders. Because of the learning hours at school from morning to evening, SDIT Salsabila makes humanizing the classroom as a learning approach, so students do not experience boredom in school. Educators and educational personnel are equipped with the principles of education and learning which is funny, appreciate the students' honour as a whole person, the school situation that enables the development of students' talents and interests, and the role of educators in lieu of parents are always emphasized in school management.

\subsubsection{Purpose and Process of Education in SDIT Salsabila}

In the concept of humanizing the classroom, the objectives and learning process applied is children's initiative. Therefore, curriculum and educational objectives must be in accordance with the needs and interests of children. The curriculum serves to provide valuable experience to help facilitate students' development. The goal of education is dynamic process of personal development and directed to the growth, integrity, and autonomy of personality, a healthy attitude toward themself, others, and learning.

At SDIT Salsabila, and almost all schools throughout Indonesia, the vision, mission, and objectives of the school should refer to the goals achievement of the national education system. Therefore, the educational goals formulation in schools is a set of plans that must be achieved by schools to achieve national education objectives. The curriculum and learning activities in the class should refer to it.

Vision of SDIT Salsabila prepared by the manager of the foundation with the stake holders. While the teachers, employees, and students are limited to getting socialization, and then together trying to realize it in the learning. This data was obtained through an interview with teacher of SDIT Salsabila.

Students are not involved in formulating learning objectives because the learning objectives already exist in the curriculum. What we do is how before the learning activities all students understand about the purpose of learning. So it's like a trip, all travel participants already know the direction of the journey (Interview with MA, Teacher of SDIT Salsabila). 
In Indonesia, the curriculum in schools has indeed been formulated by curriculum centers under the Ministry of Education and Culture. Formally, schools do not have the flexibility to formulate the curriculum. The flexibility of the school lies in the implementation of the learning process in the classroom. This is consistent with the results of interview with teacher of SDIT Salsabila as follows.

Every beginning of learning, we conveys what students will achieve and learn. So students know the purpose of learning from the beginning. But if the formulation of learning goals already exist in the curriculum, we just do it (Interview with SL, Teacher of SDIT Salsabila).

\subsubsection{Students as Subject of Learning}

Humanizing the classroom requires students to be active subjects, not passive objects. Children will enthusiastically learn if they are given the opportunity to learn according to their talents and interests, not because of coercion from the teacher.

As a subject of learning, students are required to play an active role in learning in the classroom. Teachers are also required only as a facilitator, not a class controller. Based on interviews and observations, the researchers found that the students' active participation in the classroom shows from students enthusiastic to ask questions, discussions, and in certain subjects they presented projects given by teachers in the classroom.

To support students' activeness as a learning subject at school, the curriculum developed by SDIT Salsabila also focuses on the potential, development, needs, and interests of learners and their environment.

SDIT Salsabila curriculum is developed based on the principle that learners have a central position to develop their potential and competence to become human beings who are faithful and devout to God Almighty, proficient, intellect and noble, and to be creative, independent and democratic citizens, also responsible (SDIT Salsabila Curriculum Documentation).

The above formulations show that the curriculum developed at SDIT Salsabila is oriented towards the development of potential learners. The curriculum is formulated in order to become tool for learners to develop themselves so that they become full-fledged human beings with characteristics as they are in the national education objectives. Learning activities held are learners-centered. Interview with teacher also show similar principle.

We always actively involve students in learning because they are the subject of learning. I give the widest opportunity to students to ask questions, discuss, and even help other students to answer questions (Interview with ZA, Teacher of SDIT Salsabila).

Render students as an important subject in the learning process in the classroom is an important element in the application of humanizing the classroom. This is in line with the results of previous research which stated that teachers and students as learners are the main elements in the application of humanizing the classroom (Nwafor, 2014; Bhatia, 2000).

\subsubsection{The Teachers' Role as Facilitator}

In the concept of humanizing the classroom, teachers have very important role in learning in the classroom. Bhatia (2000) revealed that the teachers play a prominent role in humanizing the classroom and even beyond the school environment. They are an important factor in the educative process, given their personal qualities, professional training, and the place they also occupy in the community.

Good teachers are teachers who understand the needs of students in the classroom and have closeness, even know the names of students in the classroom. Okorie (1986) explained that a good teacher can create a comfortable while the lesson is in progress. Such a teacher, according to Onoguere (2000) can be fair, have a good and straight commitment in assisting students in the classroom.

As a facilitator, the teachers is tasked with giving advice, guiding, and learning partners, not the class authorities. In SDIT Salsabila, several principles of humanizing the classroom as above have been implemented by the teachers. Based on the results of the interviews, the teachers revealed that the main role of teachers in the school is as a facilitator for their students. As facilitators, they strive to design all the learning components in the classroom to function properly so that students can achieve the stated learning objectives. Teachers place students as learning subject who comfortably doing process of search, discover, and to become during the classroom learning process.

The teacher's main role is to become a facilitator and to be a companion in learning. The difference between learning at the old times is, for example, we compare when I went to elementary school with my students now, previously teacher who always gave lecture in front of the class, now students have to present actively in class. Therefore, the teacher is a facilitator and assistant in the class (Interview with MZ). 
This data is corroborated by another teacher who stated that:

The main role of teacher in the classroom is to be a facilitator, to be a mentor and even the hallmark of our school is a teacher as well as a substitute for parents. Thus, students will gain not only formal lessons in the class but their psychological needs are also fulfilled (Interview with WR, teacher of SDIT Salsabila).

Those interviews are similar to the research of Hoy and Miskel. Teachers' significance in creating a humanist class as Hoy and Miskel (2008) stated that teachers have experience using behavioural theory in their teaching. Woolfock (2007) corroborates the principles in humanizing the class; provide clear and systematic praise, recognition of students achievement; recognition of students positive behaviours, setting clear and specific goals, linking students' success to the efforts and abilities they have undertaken in order to build self-confidence, preferring affirmation of the negative rather than punishment, and adapting punishments to fit the student delinquency level.

Nevertheless, the results of observation indicate that the function of teachers as facilitators is just applied to certain themes only. In other words, the teacher as a facilitator has not become mainstream in the learning process at SDIT Salsabila. The role of the teacher as a substitute for the parents is another characteristic of SDIT Salsabila. This role makes students feel comfortable in school as they are at home.

\subsubsection{School is a Miniature of Society}

The principle of humanizing the classroom puts the school as a miniature of society. Schools should really be a part of people's lives. Not an entity totally separate from the life of the people. Therefore, learning activities are not limited to activities in the classroom, but educational activities can provide benefits to the community.

As a manifestation of the miniature of society, all components of education in SDIT Salsabila are designed in such a way that the school entity can perform the functions described above. Moreover, as a school that implements full day school program, the various functions of the miniature society can be run freely because it automatically has a longer time in school. The curriculum is formulated to be relevant to the needs of life.

The curriculum of SDIT Salsabila also adheres to the principle of current development. Therefore, the development of SDIT Salsabila curriculum is done by involving stakeholders to ensure the relevance of education to the needs of life, including society life, business world, and the world of work. Therefore, the development of personal skills, thinking skills, social skills, academic skills, and vocational skills are of paramount importance (SDIT Salsabila Curriculum Documentation).

As the implementation of the school's function as a miniature of society, SDIT Salsabila performs the following functions: principal, teachers and education personnel strive to cultivate norms, behaviours, moral, by giving good example in all activities and in classroom learning. In addition, the curriculum is also formulated to enable students learning throughout life.

SDIT Salsabila curriculum is also directed to the process of development, culture, and empowerment of learners that lasts for life. SDIT Salsabila curriculum aims at reflecting the interrelationship between the elements of formal, non-formal and informal education by taking into account conditions and environment's demands that constantly evolving as well as the direction of the development of full-pledged human (SDIT Salsabila Curriculum Documentation).

\subsubsection{Problem Based Learning}

Learning activities to be more focus on problem solving, not just the transfer of knowledge from teacher to student. Problem Based Learning (PBL) is a model of teaching by exposing students to authentic problems. Authentic problems can be interpreted as a problem that students often find in everyday life. With PBL students are trained to build their own knowledge, develop problem-solving skills, self-reliance and increase their confidence. In addition, by providing authentic problems, students can shape the meaning of the learning material through the learning process and store it in memory so that it can be used again at any time.

To practice this learning model can be done with various approaches. As in the interview did by the researchers, a teacher revealed:

I often use the thematic model of scientific approach. With this model, students are invited actively in learning, ranging from actively observing, asking, communicating, and concluding. So students trained to think critically since childhood. (Interview with MZ, teacher of SDIT Salsabila)

This is in line with the principles of SDIT Salsabila curriculum development which prioritizes the response to the development of science, technology and art. 
SDIT Salsabila curriculum develops on the basis of the awareness that science, technology and art are developing dynamically. Therefore, the spirit and contents of the curriculum provide learning experiences for learners to follow and utilize the development of science, technology and art (SDIT Salsabila Curriculum Documentation).

With settings of learning as described above, students are expected to have practical skills so that they can solve many problems encountered in the real world.

\subsubsection{Democratic Climate in School}

Humanizing the classroom also requires a growing democratic climate in school. School climate must ensure a democratic and cooperative atmosphere. Therefore, all parties, such as principal, teachers, education personnel and students must have the same role. In SDIT Salsabila, it shows that the role of the students is only in aspects that involve students themselves, such as arranging schedules of cleaning classroom and determining classroom organizational structure. As expressed by teachers in the interviews as follows:

The democratic climate in my class may only be limited when setting up the classroom organizational structure and setting the schedule of cleaning classroom. If in formal learning for example in arranging the seat students are also sometimes invited to discussion (Interview with MZ, Teacher of SDIT Salsabila).

A similar opinion was made by ZA in the interview as follows.

For example, teacher always ask students opinions about classroom rules. At the beginning of the year also undertake a learning contract. So the teacher strives to accommodate students' opinions and suggestions. So students are involved (Interview with ZA, teacher of SDIT Salsabila).

To support the democratic climate in schools, SDIT Salsabila curriculum is developed in diversity and integrated manner. This can be seen from SDIT Salsabila curriculum document as follows.

SDIT Salsabila curriculum is developed by taking into consideration the diversity of learners' characteristics, local conditions, levels and types of education, as well as respect and non-discrimination toward religion, ethnic, cultural, tradition, social, economic and gender differences (SDIT Salsabila Curriculum Documentation).

The development of curriculum that emphasizes on integrated diversity principles enables democratic learning climate in school to work well. Democratic climate will make students feel comfortable in school even though they have different backgrounds and conditions. Democratic climate is important to develop in schools due to the fact that students come from different backgrounds, and basically have different patterns of behaviour. Therefore, as revealed by Calvert (1975) students come to class with their distinctions and singularity.

\section{Discussion}

Some of the findings in this research reinforce the opinions and ideas of previous researches. First, full-day school program growing in Indonesia is due to the development of middle class in Indonesia, where they no longer have enough time to accompany their children at home. They do not have the opportunity to accompany their children at home because they are busy working from morning to evening. Therefore, the full day school program is an alternative which is right for them.

This reason is in line with previous research. Arshadana (2010) stated that parents who busy with work make schools that implement full-day programs as an alternative to educate their children. Research that stated full-day school programs cause lack of social interaction and social awareness (Andikurrahman, 2012) is anticipated by school managers by applying flexible hours so as well as an arena for students to interact and train social awareness with peers in schools and surrounding communities.

In addition, research on full-day school that showed full-day school practice can help students to improve academic, social, moral, emotional and even parental satisfaction (Cannon, Jacknowitz, \& Painter, 2006; Kauerz, 2005; Cooper, Allen, Patall, \& Dent, 2010; Ray \& Smith, 2010; Clark \& Kirk, 2000; Fusaro \& Royce, 1995; Gullo, 2000) also factors to strengthen the development of schools that implementing a full-day system.

Second, the concept of humanizing the classroom in SDIT Salsabila is understand by principal, teachers, and education personnel as a learning approach that makes students as active subject in learning. These results support the idea that students are the subject of learning, not the object of learning (Reardon, 2001; Nwafor, 2014; Kuntoro, 2008; Titus, 1979).

Humanizing the classroom is implemented through the active involvement of students in applying all the learning components. This approach is a solution so that students do not feel tired of learning even though they spend all day 
in school. The principles of learning while playing and the availability of adequate rest time in school makes students feel comfortable and not feel boredom at school. These results confirm the idea that the implications of humanizing the class room will lead to a reciprocal relationship between teachers and students; a situation which in turn leads to mutual understanding and cooperation. Such a situation can lead to the dignity of the students being respected, while the integrity of the teacher is also respected Nwafor, 2014). The learning climate that respects the students' honour and dignity as a human can ultimately improve the students' academic achievement, and also positively impact social and emotional development. Therefore, the full day school system is likely to still get a positive response in the community in the times to come as it can be an educative solution for parents, especially from middle class who are busy working.

\section{Acknowledgments}

The researchers express sincere thanks to those who have been involved and assisted with the completion of this research and the writing of this article, especially to Ahmad Dahlan University who has funded this research and to the resource persons who have provided very important data. And also, researchers are very grateful to the editor and reviewers who have provided invaluable inputs for improvement.

\section{References}

Andikurrahman. (2012). Dampak Pelaksanaan Full Day School Terhadap Perkembangan Sosial Peserta Didik (Studi Kasus di SD Plus Nurul Hikmah Pamekasan). Tesis. Department of Tarbiyah. Study Program of Pendidikan Agama Islam, STAIN Pamekasan.

Arsyadana, A. (2010). Penerapan Sistem Full Day School Sebagai Upaya Untuk Meningkatkan Kualitas Pendidikan Di Mi Al-Qamar Nganjuk. Skripsi. UIN Malang.

Basketta, R., Bryanta, K., Whitea, W., \& Rhoads, K., (2005). Half-day to full-day kindergarten: An analysis of educational change scores and demonstration of an educational research collaboration. Early Child Development and Care, 175(5), 419-430. https://doi.org/10.1080/0300443042000266259

Bhatia, K. K. (2000). Principles of Education. New Delhi: Kalyani Publishers.

Burdumy, S. J., Dynarski, M., \& Deke, J. (2006). After School Program Effects on Behavior: Results from the 21st Community Learning Centers Program National Evaluation. Retrieved from http://athens.src.uchicago.edu/jenni/EI/Burdumyetal/Burdumy_Dynarski_etal_EI_final.pdf

Calvert, B. (1975). The Role of the Pupil. London: Routledge and Kegan Paul.

Cannon, J. S., Jacknowitz, A., \& Painter, G. (2006). Is full better than half? Examining the longitudinal effects of full-day kindergarten attendance. Journal of Policy Analysis and Management, 25(2), 299-321. https://doi.org/10.1002/pam.20174

Clark, P. \& Kirk, E. (2000) All-day kindergarten: review of research. Childhood Education, 76, 228-231. https://doi.org/10.1080/00094056.2000.10521169

Cohen, L., Manion, L., \& Morrison, K. (2000). Research methods in education. London: Routledge Falmer. https://doi.org/10.4324/9780203224342

Cooper, H., Allen, A. B., Patall, E. A., \& Dent, A. L. (2010). Effects of full-day kindergarten on academic achievement and social development. Review of Educational Research, 80(1), 34-70. https://doi.org/10.3102/0034654309359185

Dina, I. (2011). Pengaruh Full Day School Terhadap Kecerdasan Sosial Anak Kelas IV DI SDIT Bina Anak Sholeh Yogyakarta. Thesis, UIN Sunan Kalijaga Yogyakarta.

Elicker, J., \& Mathur, S. (1997). What do they do all day? Comprehensive evaluation of a full-day kindergarten. Early Childhood Research Quarterly, 12, 459-480. https://doi.org/10.1016/S0885-2006(97)90022-3

Fusaro, J., \& Royce, C. (1995). A Reanalysis of Research Data. Perceptual and Motor Skills, 81, 358. https://doi.org/10.2466/pms.1995.81.3.858

Gottfredson, D. C., Gerstenblith, S. A., Soul'e, D. A., Womer, S. C., \& Lu, S. (2004). Do After School Program Reduce Delinquency? Prevention Science, 5(4). https://doi.org/10.1023/B:PREV.0000045359.41696.02

Gullo, D. (2000) The Long Term Educational Effects of Half-Day vs. Full-Day Kindergarten. Early Child Development and Care, 160, 17-24. https://doi.org/10.1080/0030443001600102

Hasan, N. (2011). Islamizing Formal Education: Integrated Islamic School and New Trend in Formal Education Institution in Indonesia. Paper, at S. Rajartanam School of International Studies Singapore. 
Heagle, K., Timmons, K., Hargreaves, F., \& Pelletier, J. (2017). The social kindergartener: comparing children's perspectives of fulland half-day kindergarten. Early Child Development and Care, 187(5-6), 978-989. https://doi.org/10.1080/03004430.2016.1199551

Holm, L. (2014). Parental perspectives on Danish full-day schools for ethnicminority students. International Journal about Parents in Education, 8(1).

Hoy, W. K., \& Miskel, C. G. (2008). Educational Administration Theory, Research, and Practice. London: McGraw-Hill.

Johnson, B., \& Christensen, L. (2000). Educational Research. Quantitative and Qualitative Approaches. Boston: Allyn and Bacon.

Kauerz, K. (2005). Full-Day Kindergarten: A Study of State Policies in the United States. Denver, CO: Education Commission of The States.

Kuntoro, S. A. (2008). Sketsa Pendidikan Humanis Religius, “Makalah”. Fakultas Ilmu Pendidikan, Universitas Negeri Yogyakarta.

Miles, M. B., \& Huberman, A. M. (1994). Qualitative data analysis. Thousands Oaks: Sage Publications.

Milner, J. P. (2001). Humanizing the Class Room. Disadur Oleh Abdul Munir Mulkhan, Cerdas Di Kelas Sekolah Kepribadian. Yogyakarta: Kreasi Wacana.

Mulkan, A. M. (2002). Cerdas di Kelas Sekolah Kepribadian: Rangkuman Model Pengembangan Kepribadian dalam Pendidikan Berbasis Kelas, saduran dari buku. Humanizing the Classroom karya John P. Miller, Kreasi Wacana, Yogyakarta.

Nwafor, N. H. A. (2014). Humanizing the class room: A pragmatic approach. European Scientific Journal, 10(19).

Okorie, J. U. (1986). Fundamentals of Teaching Practice. Enugu: Fourth Dimension Publishing Co. Ltd.

Onoguere, W. O. (2000). Introduction to General Methodology. Warri: Eregha Publishers.

Patton, M. Q. (2002). Qualitative evaluation and research methods. Newbury Park: Sage Publications.

Pianta, R. C., Cox, M. J., \& Snow, K. L. (2007). School readiness and the transition to kindergarten in the era of accountability. Baltimore, MD: Paul H Brookes Publishing.

Puleo, V. T. (1987). Methodological Issues in Full-day Kindergarten Research. Journal of Research in Childhood Education, 2(1), 56-64. https://doi.org/10.1080/02568548709594922

Ray, K., \& Smith, M. C. (2010). The kindergarten child: What teachers and administrators need to know to promote academic success in all children. Early Childhood Education Journal, 38(1), 5-18. https://doi.org/10.1007/s10643-010-0383-3

Reardon, B. A. (2001). Education for a Culture of Peace in a Gender Perspective. Paris: UNESCO Publishing.

Rudestam, K. E., \& Newton, R.R. (2001). Surviving your dissertation (2nd ed.). Thousands Oaks. Sage publications.

Sergesgetter, K., \& Gilman, D. (1988). The effect of length of time in kindergarten on reading achievement (ERIC Document Reproduction Service No. ED 324-664).

Titus, H. H., Smith, M. S., \& Nolan, R. T. (1979). Living Issues in Philosophy (7th Ed.). New York: D. Van Nostrand Company.

Wahidun. (2008). Manajemen Pengembangan Kurikulum Terpadu dengan Sistem Full day School.

Winurini, S. (2016). Wacana Penerapan Full Day School Untuk Siswa SD dan SMP. Majalah Info Singkat, Vol. VIII, No. 15/I/P3DI/Agustus/2016.

Woolfock, A. (2007). Educational Psychology. Boston: Allyn and Bacon. 


\section{Copyrights}

Copyright for this article is retained by the author(s), with first publication rights granted to the journal.

This is an open-access article distributed under the terms and conditions of the Creative Commons Attribution license (http://creativecommons.org/licenses/by/4.0/). 